\title{
PENYULUHAN ONLINE DENGAN BOOKLET DAN VIDEO SEBAGAI UPAYA PENGENDALIAN HIPERTENSI
}

\author{
Andini Octaviana Putri1), Tyas Ningrum Rahmadayanti'2), Aulia Rizka Chairunnisa²), \\ Noor Khairina'), Santi ${ }^{2}$,
}

1)Departemen KIA dan Kesehatan Reproduksi, Program Studi Kesehatan Masyarakat, Fakultas Kedokteran, Universitas Lambung Mangkurat, Banjarmasin, Kalimantan Selatan, Indonesia

2)Program Studi Kesehatan Masyarakat, Fakultas Kedokteran, Universitas Lambung Mangkurat, Banjarmasin, Kalimantan Selatan, Indonesia

Corresponding author : Tyas Ningrum Rahmadayanti

E-mail : tyasningrumr@gmail.com

Diterima 07 April 2021, Disetujui 12 April 2021

\begin{abstract}
ABSTRAK
Hipertensi atau yang lebih dikenal dengan tekanan darah tinggi adalah tekanan darah sistol yang melebihi $140 \mathrm{mmHg}$ dan tekanan darah diastol melebihi $90 \mathrm{mmHg}$. Kematian dini di dunia semakin lama semakin meningkat hal ini disebakan oleh penyakit hipertensi. Berdasarkan data Riset Kesehatan Dasar (Riskesdas) tahun 2018, prevalensi kejadian hipertensi sebesar 34,1\%. Angka ini meningkat cukup tinggi dibandingkan hasil riskesdas tahun 2013 yaitu sebesar 25,8\%. Prevalensi hipertensi tertinggi terdapat di Kalimantan Selatan (44,1\%). Tujuan penyuluhan mengenai hipertensi dapat membuat pengetahuan dan sikap warga tentang hipertensi akan semakin meningkat kemudian mendorong seseorang untuk berperilaku yang lebih baik dalam mencegah dan mengontrol hipertensi sehingga tekanan darahnya tetap terkendali, pengetahuan warga mengenai hipertensi juga berpengaruh pada kepatuhan warga yang terkena hipertensi dalam melakukan pengobatan. Kegiatan penyuluhan ini dilakukan secara daring dikarenakan adanya pandemi covid-19, menggunakan media booklet dan video berdurasi satu menit. Media booklet dan video dipilih karena praktis dan efektif. Sebanyak 15 orang mengikuti kegiatan penyuluhan daring ini dan dimasukkan di whatsapp group yang sudah dibuat agar mudah untuk melakukan koordinasi. Hasil penyuluhan ini meningkatkan pengetahuan warga dengan kategori baik sebanyak 100\% (15 orang) dan sikap dengan kategori positif sebanyak $66,7 \%$ (10 orang) tentang pengendalian hipertensi.
\end{abstract}

Kata kunci: pengendalian hipertensi; penyuluhan online; booklet; video.

\begin{abstract}
Hypertension or better known as high blood pressure is systolic blood pressure that exceeds $140 \mathrm{mmHg}$ and diastolic blood pressure that exceeds $90 \mathrm{mmHg}$. Increasingly, premature death in the world is caused by hypertension. Based on data from Basic Health Research (Riskesdas) in 2018, the prevalence of hypertension was $34,1 \%$. This figure increased quite significantly compared to the 2013 riskesdas, which was $25,8 \%$. The highest hypertension prevalence was in South Kalimantan (44,1\%). The aim of counseling on hypertension can make citizens 'knowledge and attitudes about hypertension increase and then encourage someone to behave better in preventing and controlling hypertension so that their blood pressure remains under control, residents' knowledge about hypertension also affects the compliance of residents with hypertension in taking medication. This outreach activity was carried out online due to the Covid-19 pandemic, using booklets and one-minute videos. Booklet and video media were chosen because they are practical and effective. A total of 15 people participated in this online counseling activity and were included in the WhatsApp group that had been created so that it was easy to coordinate. The results of this counseling increased the knowledge of villagers with good categories by $100 \%$ (15 people) and attitudes with positive categories by $66,7 \%$ (10 people) about controlling hypertension.
\end{abstract}

Keywords: hypertension control; online counseling; booklet; video.

\section{PENDAHULUAN}

Hipertensi atau yang lebih dikenal dengan tekanan darah tinggi adalah tekanan darah sistol yang melebihi $140 \mathrm{mmHg}$ dan tekanan darah diastol melebihi $90 \mathrm{mmHg}$.
Kematian dini di dunia semakin lama semakin meningkat hal ini disebakan oleh penyakit hipertensi (Nor'alia et al., 2019). Penyakit hipertensi dapat menyebabkan berbagai komplikasi. Peningkatan tekanan darah yang 
berlangsung dalam jangka waktu lama (persisten) dapat menimbulkan kerusakan pada ginjal (gagal ginjal), jantung (penyakit jantung koroner) dan otak (menyebabkan stroke) bila tidak dideteksi secara dini dan mendapat pengobatan yang memadai. Hipertensi mencetuskan timbulnya plak aterosklerotik di arteri serebral dan arteriol, yang dapat menyebabkan oklusi arteri, cedera iskemik dan stroke sebagai komplikasi jangka panjang (Yonata \& Pratama, 2016).

Hipertensi dapat diklasifikasikan menjadi 2 jenis, yaitu hipertensi primer $(90 \%$ kasus hipertensi) yang penyebabnya tidak diketahui dan hipertensi sekunder $(10 \%)$ yang disebabkan oleh penyakit ginjal, penyakit endokrin, penyakit jantung dan gangguan ginjal. Menurut JNC VII Report 2003, diagnosis hipertensi ditegakkan apabila didapatkan tekanan darah sistolik (TDS) $\geq 140 \mathrm{mmHg}$ dan atau tekanan darah diastolik (TDD) $\geq 90 \mathrm{mmHg}$ pada dua kali pengukuran dalam waktu yang berbeda (Kadir, 2019).

Gejala yang dialami pada hipertensi adalah dengan adanya peningkatan tekanan darah atau tergantung pada tinggi rendahnya tekanan darah. Gejala hipertensi yang timbul bisa berbeda bahkan terkadang penderita hipertensi tidak memiliki keluhan. Namun karena sering kali penderita hipertensi tidak menyadari adanya gejala, hal tersebut dapat menimbulkan keluhan pada saat sudah terjadinya komplikasi yang spesifik pada organ seperti otak, mata, ginjal, jantung, pembuluh darah, atau organ vital lainnya (Kurniawan \& Sulaiman, 2019).

Kasus hipertensi di Indonesia dan negara berkembang lainnya diperkirakan akan meningkat $80 \%$ pada tahun 2025 . Diperkirakan sebanyak 15 juta orang menderita hipertensi di Indonesia tetapi hanya $4 \%$ yang merupakan hipertensi terkontrol. Berdasarkan data Riset Kesehatan Dasar (Riskesdas) tahun 2018, prevalensi kejadian hipertensi sebesar 34,1\%. Angka ini meningkat cukup tinggi dibandingkan hasil riskesdas tahun 2013 yaitu sebesar $25,8 \%$. Prevalensi hipertensi tertinggi di Kalimantan Selatan (44,1\%) sedangkan terendah di Papua sebesar (22,2\%) (Putriastuti, 2016). Berdasarkan hasil survei pada kegiatan praktek belajar lapangan (PBL) di desa AluhAluh Besar RT.06 di dapatkan data kejadian hipertensi sebesar $18,3 \%$.

Hipertensi harus dicegah dan ditanggulangi karena hipertensi merupakan faktor risiko utama terjadinya berbagai penyakit kardiovaskuler termasuk stroke, penyakit jantung koroner, gagal jantung, dan penyakit ginjal stadium akhir atau gagal ginjal. Pola hidup yang baik, manajemen stress yang tepat serta olahraga secara teratur merupakan kunci hidup sehat yang dapat mencegah terjadinya hipertensi (Setiawan et al., 2018). Menjalankan pola hidup sehat setidaknya selama 4-6 bulan terbukti dapat menurunkan tekanan darah dan secara umum dapat menurunkan risiko permasalahan kardiovaskular (Akbar \& Tumiwa, 2020).

Pola hidup sehat untuk mencegah hipertensi yaitu diet sesuai DASH (Dietary Approaches to Stop Hypertension). Makanan DASH berupa makanan seperti buah-buahan dan sayuran segar, kacang-kacangan, kacang polong, dan produk makanan rendah lemak jenuh. Olahraga selama 30-60 menit, 4-7 kali dalam seminggu dan rutin kontrol berat badan. Menghindari alkohol dan produk olahan atau derivatnya. Berhenti merokok dan menghindari terpapar asap rokok serta dapat memanajemen stress dengan baik dan berpola hidup sehat serta seimbang (Sutoni \& Cahyati, 2021).

Faktor pengetahuan dan sumber serta akses informasi yang cukup akan meningkatkan motivasi masyarakat untuk meningkatkan kualitas hidup dengan menghindari faktor-faktor penyebab hipertensi (Setiawan et al., 2018). Semakin meningkatnya pengetahuan pasien tentang hipertensi akan mendorong seseorang untuk berperilaku yang lebih baik dalam mengontrol hipertensi sehingga tekanan darahnya tetap terkendali, pengetahuan pasien mengenai hipertensi juga berpengaruh pada kepatuhan pasien dalam melakukan pengobatan (Sofiana et al., 2018).

Pengetahuan bisa didapatkan melalui pendidikan kesehatan. Pendidikan kesehatan adalah suatu proses yang dapat meningkatkan derajat kesehatan seseorang. Pendidikan kesehatan dapat diberikan kepada seluruh sasaran, namun harus menggunakan metode serta media yang tepat dan sesuai dengan kelompok sasaran agar informasi yang diberikan dapat diterima dengan baik (Ulya et al., 2017).

Tujuan dari pendidikan kesehatan menurut Undang-Undang Kesehatan No. 23 tahun 1992 yaitu meningkatkan kemampuan masyarakat untuk memelihara dan meningkatkan derajat kesehatan baik fisik, mental, dan sosialnya sehingga produktif secara ekonomi maupun secara sosial, pendidikan kesehatan disemua program kesehatan baik pemberantasan penyakit menular, sanitasi lingkungan, gizi masyarakat pelayanan kesehatan maupun program kesehatan lainnya.

Penyuluhan merupakan salah satu metode pendidikan kesehatan yang efektif dan sering dilakukan untuk memberikan infromasi kesehatan kepada masyarakat. Informasi yang 
didapatkan dari penyuluhan dapat memberikan pengaruh jangka pendek sehingga dapat menghasilkan perubahan atau peningkatan pengetahuan. Pemberian penyuluhan dapat menghasilkan suatu perubahan dari yang semula belum mengetahui menjadi mengetahui dan yang belum memahami menjadi memahami.

Hipertensi menjadi permasalahan di RT.06 Desa Aluh-Aluh Besar yang datanya telah di dapatkan pada kegiatan PBL I. Namun, dikarenakam pandemi Covid-19 maka intervensi yang sudah direncanakan pada PBL I harus dimodifikasi menjadi penyuluhan melalui Whatsapp mengenai hipertensi dan juga Covid-19. Setelah dan sebelum dilakukan intervensi, warga diberikan pre dan post-test melalui google formulir.

Kegiatan Pengalaman Belajar Lapangan ini akan fokus pada peningkatan pengetahuan dan kesadaran masyarakat mengenai pencegahan dan pengendalian hipertensi serta pencegahan penularan covid-19. Kegiatan ini akan dilakukan dengan mengikutsertakan masyarakat secara langsung mulai dari perencanaan hingga evaluasi kegiatan. Sehingga dapat diharapkan agar program ini akan terus berlanjut secara swadaya oleh masyarakat meskipun kegiatan Pengalaman Belajar Lapangan telah selesai.

\section{METODE \\ Subjek Kegiatan}

Kegiatan ini dilaksanakan untuk meningkatkan pengetahuan dan kesadaran masyarakat mengenai pencegahan dan pengendalian hipertensi serta pencegahan Covid-19 yang dilaksanakan secara Daring atau Online community-based intervention. Pemberdayaan kepada masyarakat dilakukan melalui bantuan media online yaitu whatssapp group (WAG) dengan booklet dan video sebagai media penyuluhan. Sasaran dalam kegiatan ini berjumlah 15 orang. Pengetahuan dan sikap masyarakat terkait hipertensi akan diukur sebelum dan sesudah intervensi sehingga dapat dilihat perubahan pengetahuan dan sikap masyarakat.

\section{Tahapan Kegiatan \\ Perencanaan dan Persiapan}

Tahap perencanaan dan persiapan dalam melaksanakan kegiatan Pengalaman Belajar Lapangan (PBL) 2 yang dilakukan oleh kelompok 24 RT.06 di Desa Aluh-Aluh Besar dilakukan secara daring.

Adapun perencanaan dan persiapan yang dilakukan antara lain sebagai berikut.

1. Perizinan ke Desa
Sebelum melakukan intervensi secara daring, tim UP PBL melakukan perizinan terlebih dahulu ke masing-masing desa yang ada di Kecamatan Aluh-Aluh. Tim UP PBL melakukan koordinasi dengan kepala desa dan RT dari masing-masing desa untuk menyampaikan mekanisme Pengalaman Belajar Lapangan (PBL) 2 ini yang dilaksanakan secara daring.

2. Mengumpulkan Kontak Masyarakat Sasaran yang akan di Intervensi

Sebelum dilakukannya kegiatan Pengalaman Belajar Lapangan (PBL) 2 ini, terlebih dahulu dari dari tim UP PBL beserta mahasiswa melakukan pengumpulan kontak masyarakat yang dijadikan sasaran dalam kegiatan intervensi. Kontak yang dikumpulkan disini adalah kontak yang terdaftar dalam whatsapp karena kegiatan dilaksanakan via grup whatsapp (WAG). Ketentuan jumlah minimal kontak masyarakat yang dimiliki sebanyak 15 kontak.

\section{Membuat Grup Whatsapp}

Setelah dilakukan proses pengumpulan kontak masyarakat Desa Aluh-Aluh Besar RT.06 kemudian para anggota kelompok menghubungi kontak yang didapatkan untuk perkenalan dan meminta izin ingin memasukkan ke dalam grup whatsapp. Setelah mendapatkan izin dari kontak yang dihubungi maka dilanjutkan dengan pembuatan grup whatsapp dengan nama "Grup Penyuluhan RT 6 " yang dibuat oleh ketua kelompok. Dalam grup tersebut terdapat warga Desa Aluh-Aluh Besar RT 06 sebanyak 18 orang, anggota kelompok 24 sebanyak 4 orang serta dosen pembimbing kelompok 24.

4. Rapat Persiapan Kegiatan

Setelah membuat grup whatsapp, kelompok melakukan rapat persiapan yang membahas terkait rangkaian kegiatan, metode kegiatan dan media kegiatan yang akan dilakukan pada kegiatan intervensi Pengalaman Belajar Lapangan (PBL) 2 ini. Rapat persiapan dilakukan via online melalui grup whatsapp kelompok 24.

5. Penyusunan Prepost, Materi, dan Media yang Digunakan dalam Intervensi

Setelah kelompok melakukan rapat persiapan, dilanjutkan dengan penyusunan dan pembuatan prepost, materi dan media yang digunakan dalam kegiatan intervensi Pengalaman Belajar Lapangan (PBL) 2 ini. Kelompok membuat soal prepost pilihan ganda sebanyak 20 soal yang terbagi menjadi 10 soal tentang pengetahuan terhadap penyakit hipertensi dan 10 soal tentang sikap terhadap penyakit hipertensi. Untuk prepost Covid-19 kelompok membuat soal pilihan ganda sebanyak 10 soal yang terbagi menjadi 5 soal 
tentang pengetahuan terhadap Covid-19 dan 5 soal tentang sikap terhadap Covid-19. Soalsoal prepost dari kelompok 24 berkaitan dengan materi yang akan disampaikan yaitu terkait dengan hipertensi, faktor risiko hipertensi dan pengendalian hipertensi serta cara mencegah penularan corona virus (Covid19).

6. Konsultasi Prepost, Materi, dan Media Kepada Dosen Pembimbing

Soal pre dan post, materi dan media yang akan digunakan dalam kegiatan intervensi yang sudah dibuat serta disusun selanjutnya dikonsultasikan kepada dosen pembimbing dan menunggu persetujuan.

\section{Penyusunan Jadwal Kegiatan}

Persiapan terakhir yang dilakukan adalah penyusunan jadwal kegiatan intervensi Pengalaman Belajar Lapanga (PBL) 2 secara internal kelompok. Walaupun sudah ada timeline yang telah diberikan oleh tim UP PBL, penyusunan jadwal kegiatan ini diharapkan dapat meperlancar jalannya kegiatan.

\section{Pelaksanaan dan Proses}

Melakukan kegiatan berupa penyuluhan terkait hipertensi dan Covid-19 kepada masyarakat Desa Aluh-Aluh Besar RT 06 dengan jumlah peserta sebanyak 18 orang. Kegiatan dilaksanakan melalui Grup whatsapp Desa Aluh-Aluh Besar RT 06, yang dihadiri oleh pembimbing dan warga RT 06. Dalam kegiatan ini, hari pertama dilakukan pembagian soal pretest kepada peserta untuk mengetahui seberapa besar pengetahuan peserta tentang materi yang akan disampaikan oleh mahasiswa. Setelah seluruh peserta selesai menjawab soal pre-test tersebut dua hari berikutnya dilanjutkan dengan inti acara yaitu pemberian materi mengenai hipertensi.

Dalam kegiatan ini warga yang berperan aktif dalam mengisi pre-test hanya berjumlah 15 orang dari total 18 orang warga RT.06 yang berada di dalam grup penyuluhan. Pemberian materi hipertensi dan Covid-19 tidak dilakukan di hari yang sama, materi covid-19 diberikan seminggu setelah warga sudah mengisi post-test mengenai hipertensi. Materi yang dibagikan berupa PPT, booklet dan vidio mengenai hipertensi dan materi berupa booklet dan video mengenai Covid-19 di Grup whatsapp Desa Aluh-Aluh Besar RT 06 yang pemberian materinya diberikan oleh Mahasiswa Kesehatan Masyarakat kelompok 24 PBL agar warga dapat membaca serta mendengarkan dari materi yang diberikan.

\section{Monitoring dan Evaluasi}

Monitoring dan evaluasi atau monev merupakan kegiatan yang ditujukan pada suatu program yang sedang atau sudah berlangsung yang bertujuan untuk melihat perkembangan masyarakat desa Aluh-Aluh Besar RT 06 yang dilakukan. Monitoring salah satu aktivitas yang dilakukan pimpinan untuk melihat, memantau jalannya organisasi selama kegiatan berlangsung dan menilai ketercapaian tujuan, melihat faktor pendukung dan penghambat pelaksanaan program. Evaluasi dari program ini dapat dilihat dari meningkatnya pengetahuan sasaran terkait pencegahan hipertensi dan Covid-19 dengan menilai apakah pengetahuan yang telah dimiliki masyarakat dimanfaatkan secara efektif dan efisien dilihat dari hasil pre test dan post test yang telah diberikan.

\section{HASIL DAN PEMBAHASAN}

Kegiatan penyuluhan ini dilakukan secara daring dikarenakan adanya pandemi covid-19. Sebanyak 15 warga mengikuti kegiatan penyuluhan daring ini dan dimasukkan di whatsapp group yang sudah dibuat agar mudah untuk melakukan koordinasi, karakteristik warga dapat dilihat pada tabel 1 .

Tabel 1. Karakteristik Warga

\begin{tabular}{|c|c|c|}
\hline Karateristik & $\mathbf{N}$ & $\%$ \\
\hline \multicolumn{3}{|l|}{ Jenis Kelamin } \\
\hline - Laki-laki & 4 & 26,7 \\
\hline - Perempuan & 11 & 73,3 \\
\hline \multicolumn{3}{|l|}{ Kelompok Umur } \\
\hline - 17-25 tahun & 2 & 13,3 \\
\hline - 26-35 tahun & 6 & 40 \\
\hline - $36-45$ tahun & 4 & 26,7 \\
\hline - $46-55$ tahun & 3 & 20 \\
\hline \multicolumn{3}{|l|}{ Tingkat Pendidikan } \\
\hline - Rendah & 6 & 40 \\
\hline - Tinggi & 9 & 60 \\
\hline \multicolumn{3}{|l|}{ Riwayat Hipertensi } \\
\hline - $\mathrm{Ya}$ & 6 & 40 \\
\hline - Tidak & 9 & 60 \\
\hline
\end{tabular}

Hal pertama yang dilakukan setelah semua warga masuk di whatsapp group adalah perkenalan tim lalu pembagian link google form yang berisi pre-test kemudian pembagian media penyuluhan yaitu booklet dan video selanjutnya diskusi kecil dan terakhir pembagian link google form yang berisi posttest.

Kegiatan penyuluhan ini menggunakan media booklet dan video berdurasi satu menit. Media booklet dan video dipilih karena praktis dan efektif. Booklet adalah media cetak yang memiliki paling sedikit lima halaman dan paling banyak empat puluh delapan halaman tetapi tidak termasuk dalam hitungan sampul, yang dijilid di bagian tengah sekaligus dengan sampulnya dan desain yang menarik. Namun 
pada kegiatan ini hanya dibagikan dalam format pdf saja. Booklet berisi materi tentang pengertian, gejala (Gambar 1), faktor risiko, pengendalian dan pencegahan hipertensi, serta informasi mengenai makanan yang harus dikurang dan dibatasi oleh penderita hipertensi. Penelitian yang dilakukan oleh Wijayanti dan Budhi M (2018) menyatakan bahwa dengan pemberian pendidikan kesehatan menggunakan booklet lebih efektif dibandingkan dengan memberikan pendidikan kesehatan hanya dengan kemampuan bicaranya sesuai dengan pengetahuan yang didapatkan. Media booklet lebih menarik dan lebih memfokuskan pada pasien, sehingga apa yang disampaikan mudah diterima oleh pasien (W. Wijayanti \& Mulyadi, 2018).

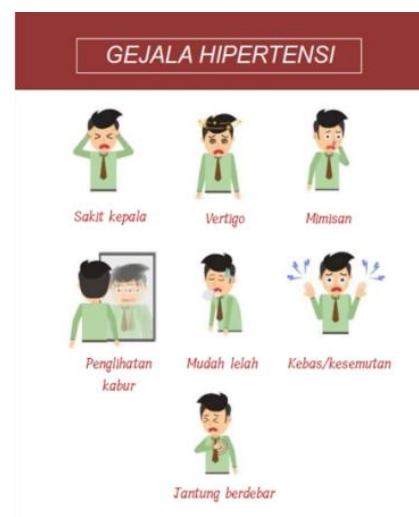

Gambar 1. Isi Booklet

Video adalah media yang menggabungkan audio, visual dan animasi yang memiliki pesan dan memiliki daya tarik sendiri atau mungkin menjadi pesan persuasif kepada responden (Puspitasari \& Sunarsih, 2020). Video berisi persuasive mengenai pengendalian hipertensi (Gambar 2). Penelitian yang dilakukan Novaria W, dkk (2019) menyatakan bahwa penggunaan media video mempunyai dampak yang lebih pada penyuluhan kesehatan karena mengandalkan pendengaran dan penglihatan dari sasaran, menarik, pesan yang disampaikan dengan cepat dan mudah diingat dan dapat mengembangkan pikiran (N. Wijayanti et al., 2019).

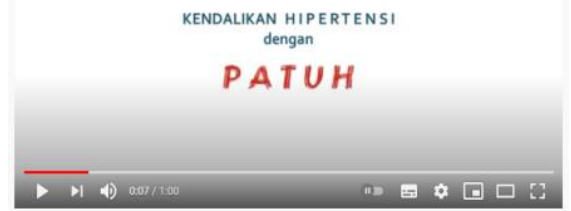

Gambar 2. Isi Vidio
Pengetahuan dan sikap warga mengenai hipertensi sebelum dilakukan penyuluhan didominasi oleh pengetahuan baik dan sikap positif hal ini terjadi karena warga sudah sering terpapar informasi mengenai hipertensi dari puskesmas atau dari media massa lain. Hasil kegiatan penyuluhan ini dapat dilihat pada perubahan pengetahuan (Gambar 3) dan sikap (Gambar 4) warga:

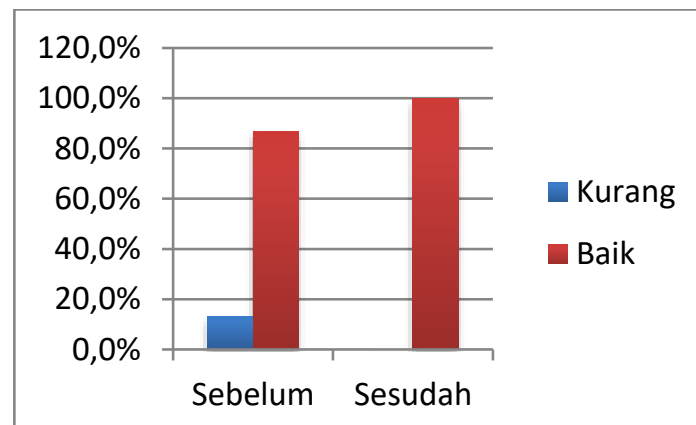

Gambar 3. Grafik Perubahan Pengetahuan Warga

Peningkatan pengetahuan warga menunjukkan bahwa penyuluhan yang diberikan kepada warga dapat diterima dengan baik. Dalam meningkatkan pengetahuan kesehatan seseorang perlu dilakukan penyuluhan kesehatan sebagai upaya mempengaruhi seseorang maupun kelompok terhadap kesehatn. Pemahaman seseorang diperoleh melalui pengetahuan yang merupakan hasil dari tahu dan ini terjadi setelah orang melakukan pengindraan terhadap suatu objek tertentu. Pengindraan terjadi melalui pancaindra manusia, yakni indra penglihatan, pendengaran, penciuman, rasa dan raba. Sebagian besar pengetahuan manusia diperoleh melalui mata dan telinga. Pengetahuan adalah domain yang sangat penting dalam pembentukan perilaku seseorang (Notoatmodjo, 2014). Perilaku yang dilandasi oleh pengetahuan akan lebih bertahan lama daripada perilaku yang tidak didasari oleh pengetahuan (Purwati et al., 2014). Seorang penderita hipertensi atau yang memiliki faktor risiko seharusnya memiliki pengetahuan yang baik mengenai hipertensi karena orang tersebut menjadi tanggung jawab untuk dirinya sendiri dalam mengontrol tekanan darahnya.

Hipertensi dapat dicegah dan dikendalikan salah satu caranya dengan meningkatkan pegetahuan warga melalui pendidikan kesehatan berupa penyuluhan. Penelitian yang dilakukan oleh Yusdianti RS dan Wiwin P (2018) menyatakan bahwa ada pengaruh pendidikan kesehatan tentang 
hipertensi terhadap pengetahuan hipertensi (Sari \& Wiwin Priyantari, 2018). Penelitian yang dilakukan Amila, dkk (2018) menyatakan pengetahuan yang baik akan berhubungan dengan self efficacy dan gaya hidup penderita hipertensi. Pengetahuan dapat menyadarkan untuk melakukan gaya hidup yang sehat (Amila et al., 2018).

Penelitian yang dilakukan oleh Riri M dan Dary PS (2017) menyatakan perilaku pengendalian tekanandarah sangat dipengaruhi oleh pengetahuan yang dimiliki oleh penderita hipertensi. Responden yang berpengetahuan rendah berarti tidak mampu mengetahui, mengerti dan memahami arti, manfaat, dan tujuan mengendalikan tekanan darah. Dengan adanya pengetahuan yang tinggi maka penderita hipertensi akan lebih termovasi untuk melakukan pengendalian tekanan darahnya (Maharani \& Syafrandi, 2017).

Adanya penyuluhan mengenai hipertensi dapat membuat pengetahuan warga tentang hipertensi akan semakin meningkat kemudian mendorong seseorang untuk berperilaku yang lebih baik dalam mencegah dan mengontrol hipertensi sehingga tekanan darahnya tetap terkendali, pengetahuan warga mengenai hipertensi juga berpengaruh pada kepatuhan warga yang terkena hipertensi dalam melakukan pengobatan. Seiring dengan meningkatnya pengetahuan tentang hipertensi maka dapat melakukan penatalaksanaan penyakitnya sehingga warga menjadi lebih baik (Sofiana et al., 2018).

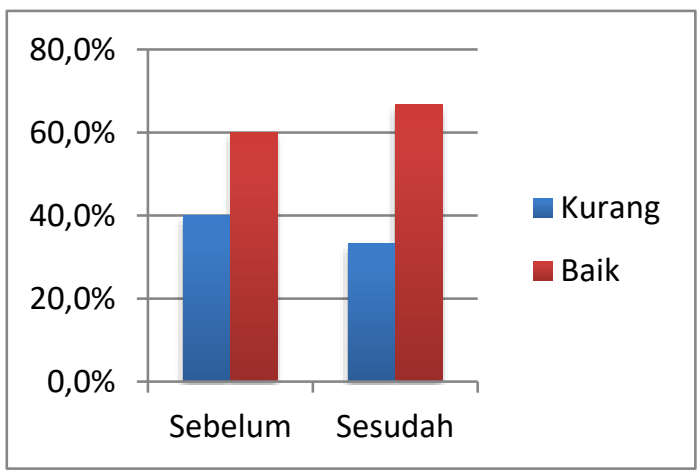

Gambar 4. Grafik Perubahan Sikap Warga

Peningkatan sikap warga ini
menunjukkan bahwa penyuluhan yang
diberikan kepada warga dapat diterima dengan
baik. Sikap adalah respon atau reaksi dari
sesorang terhadap suatu objek dan tidak dapat
dilihat secara langsung, tetapi hanya ditafsirkan
oleh perilaku tertutup. Sikap mempunyai tiga
komponen yaitu keyakinan, ide, dan konsep
terhadap suatu objek; kehidupan emosional
atau evaluasi terhadap suatu objek; dan
kecenderungan untuk bertindak (Notoatmodjo,

2014). Penentuan sikap yang utuh, pengetahuan, pikiran, keyakinan dan emosi memegang peranan penting. Maka dari itu, sikap dan pengetahuan tidak dapat dipiusahkan, pengetahuan yang baik akan menghasilkan sikap yang baik pula. Sikap warga mengenai hipertensi dimulai ketika warga memperoleh informasi atau pengetahuan tentang penyakit hipertensi, kemudian respoden tersebut menyikapinya.

Sikap warga mengenai hipertensi dapat dimulai ketika warga memperoleh informasi atau pengetahuan tentang penyakit hipertensi, kemudian warga tersebut menyikapinya. Penelitian yang dilakukan oleh Hidayati N, dkk (2020) menyatakan bahwa penerimaan informasi atau pengetahuan sangat mempengaruhi sikap dan perlakuan seseorang terhadap hipertensi (Nurhasana et al., 2020). Sikap yang positif akan menunjukan bahwa orang tersebut memiliki pengetahuan yang positif. Kemudian sikap yang positif dapat menimbulkan perilaku atau tindakan yang positif pula. Penelitian yang dilakukan oleh Riri M dan Dary PS (2017) menyatakan bahwa sikap yang negative memberi kemungkinan besar terhadap perilaku pengandalian tekanan darah yang tidak baik dibandingkan dengan sikap positif, misalnya penderita hipertensi malas mengontrol tekanan darah dan tidak mengkonsumsi obat hipertensi sesuai anjuran dokter (Maharani \& Syafrandi, 2017). Penelitian yang dilakukan oleh Nur Ainiyah dan Lono Wijayanti (2019) menyatakan bahwa sikap dapat meminimalkan terjadi kekambuhan pada penderita hipertensi (Ainiyah \& Wijayanti, 2019). Upaya preventif berupa pengaturan pola hidup penderita hipertensi sangat penting untuk membentuk sikap meminimalkan kekambuhan hipertensi.

\section{SIMPULAN DAN SARAN}

Sebelum intervensi seluruh responden $(100 \%)$ sudah memiliki pengetahuan baik mengenai hipertensi dan sebanyak 13 responden $(86,7 \%)$ sudah memilki sikap baik mengenai hipertensi dan setelah dilakukan intervensi sebanyak 15 responden (100\%) memiliki sikap baik mengenai hipertensi.

Diharapkan mahasiswa dapat memperdalam kemampuan menjadi fasilitator dan meningkatkan kemampuan berkomuniasi kepada public (public speaking) terutama kepada masyarkat dalam melakukan promosi kesehatan. Masyarakat RT. 06 Desa Aluh-Aluh Besar untuk bisa meningkatkan pengetahuan dan sikap mengenai hipertensi dan covid-19 agar dapat diimplemetasikan di kehidupan sehari-hari. Instansi Kesehatan (Dinas Kesehatan/Puskesmas) dapat lebih 
memberikan bantuan pemikiran dan tenaga serta ilmu dalam melakukan penetuan prioritas masalah kesehatan hipertensi dan juga program intervensi yang akan dilakukan kelak.

\section{UCAPAN TERIMAKASIH}

Ucapan terimakasih kepada pihak yang mendukung pelaksanaan kegiatan ini sehingga dapat terlaksana dengan baik. Tim penulis mengucapkan terima kasih kepada UP PBL, para doseni serta warga RT. 6 Desa Aluh-Aluh Besar Kecamatan Aluh-Aluh Kabupaten Banjar yang sudah mengikuti kegiatan ini dengan baik.

\section{DAFTAR RUJUKAN}

Ainiyah, N., \& Wijayanti, L. (2019). Hubungan Sikap Tentang Hipertensi Dengan Frekuensi Kekambuhan Hipertensi Pada Penderita Hipertensi Di Rw 06 Karah Kecamatan Jambangan Surabaya. Jurnal IImiah Keperawatan (Scientific Journal of Nursing), 5(1), 47-53. https://doi.org/10.33023/jikep.v5i1.214

Akbar, H., \& Tumiwa, F. F. (2020). Edukasi Upaya Pencegahan Hipertensi pada Masyarakat di Kecamatan Passi Barat Kabupaten Bolaang Mongondow. JPKMI (Jurnal Pengabdian Kepada Masyarakat Indonesia), 1(3), 154-160.

Amila, A., Sinaga, J., \& Sembiring, E. (2018). Self Efficacy dan Gaya Hidup Pasien Hipertensi. Jurnal Kesehatan, 9(3), 360. https://doi.org/10.26630/jk.v9i3.974

Kadir, S. (2019). Pola Makan Dan Kejadian Hipertensi. Jambura Health and Sport Journal, 1(2), 56-60. https://doi.org/10.37311/jhsj.v1i2.2469

Kurniawan, I., \& Sulaiman. (2019). Exercise Relationships, Stress and Eating Patterns with Hypertension Levels in Posyandu Lansia In Sudirejo Village I Sub District Medan City. Jhsp, 1(1), 10-17.

Maharani, R., \& Syafrandi, D. P. (2017). Faktor Yang Berhubungan Dengan Perilaku Pengendalian Tekanan Darah Pada Penderita Hipertensi Di Puskesmas Harapan Raya Kota Pekanbaru Tahun 2016. Jurnal Kesehatan Komunitas, 3(5), 165-171.

https://doi.org/10.25311/keskom.vol3.iss5 .122

Nor'alia, Lestari, D. R., \& Rachmawati, K. (2019). Hubungan Gaya Hidup Dengan Kejadian Hipertensi Pada Usia Dewasa Di Desa Sapala Kecamatan Paminggir Kabupaten Hulu Sungai Utara. Nerspedia, 2(1), 77-86.

Notoatmodjo, S. (2014). Promosi Kesehatan dan Perilaku Kesehatan. Jakarta: Rineka Cipta, 2014.
Nurhasana, H., Mahmud, N. U., \& Sididi, M. (2020). Gambarn Pengetahuan dan Sikap Pencegahan Kekambuhan Hipertensi pada Penderita Hipertensi Di puskesmas Antang Kota Makassar. Window of Public Health Journal, 1(2), 157-165.

Purwati, R. D., Bidjuni, H., \& Babakal, A. (2014). Perilaku Klien Hipertensi Di Puskesmas Bahu Manado. Journal Keperawatan, 2(2), 1-8.

Puspitasari, D., \& Sunarsih, T. (2020). The Effectiveness of Education Video and Booklet Media for Pregnant Mothers Knowledge on Preparation of Breastfeeding Practice. Advances in Health Sciences Research, volume 34 Proceedings of the International Conference on Health and Medical Sciences (AHMS 2020), 219-221. https://doi.org/10.2991/ahsr.k.210127.09

Putriastuti, L. (2016). Analisis hubungan antara kebiasaan olahraga dengan kejadian hipertensi pada pasien usia 45 tahun keatas. Jurnal Berkala Epidemiologi, 4(2), 225-236. https://doi.org/10.20473/jbe.v4i2.2016.25

Sari, Y. R., \& Wiwin Priyantari. (2018). Pengaruh pendidikan kesehatan tentang hipertensi terhadap pengetahuan lansia dalam mencegah hipertensi di Panti Wredha Budhi Dharma Yogyakarta. Journal of Chemical Information and Modeling, 53(9), 1689-1699.

Setiawan, H., Suhanda, S., Rosliati, E., Firmansyah, A., \& Fitriani, A. (2018). Promosi Kesehatan Pencegahan Hipertensi Sejak Dini. ABDIMAS: Jurnal Pengabdian Masyarakat, 1(2), 41-45. https://doi.org/10.35568/abdimas.v1i2.38

Sofiana, L., Puratmadja, Y., Sari, B. S. K., Pangulu, A. H. R., \& Putri, I. H. (2018). Pengetahuan Tentang Hipertensi Melalui Metode Penyuluhan. Jurnal Pemberdayaan: Publikasi Hasil Pengabdian Kepada Masyarakat, 2(1), 171. https://doi.org/10.12928/jp.v2i1.443

Sutoni, A., \& Cahyati, A. Y. (2021). Penyuluhan Pengaturan Pola Hidup Sehat dalam Upaya. Ikraith-Abdimas, 4(1), 8-18. https://journals.upi-

yai.ac.id/index.php/IKRAITHABDIMAS/art icle/download/874/662

Ulya, Z., Iskandar, A., \& Asih, F. T. (2017). Pengaruh Pendidikan Kesehatan Dengan Media Poster Terhadap Pengetahuan Manajemen Hipertensi Pada Penderita Hipertensi. Jurnal Keperawatan Soedirman, $\quad 12(1)$, 38. https://doi.org/10.20884/1.jks.2017.12.1.7 15 
Wijayanti, N., Triyanta, \& Ani, N. (2019).

Efektifitas Penyuluhan Kesehatan Sadari

Dengan Media Video Terhadap

Pengetahuan Pada Remaja Putri Di Smk

Muhammadiyah Cawas Klaten

Effectiveness Of Sadari Health Education

Using Video On Adolescent Girls

Knowledge In Muhammadiyah Cawas

Klaten Vocational $H$. Jurnal IImu Kesehatan Masyarakat Berkala, 1(1), 4958.

Wijayanti, W., \& Mulyadi, B. (2018). Pendidikan Kesehatan Menggunakan Booklet Terhadap Pemahaman Pasien Hipertensi Di Puskesmas. Jurnal IImiah IImu Keperawatan Indonesia, 8(01), 372-739. https://doi.org/10.33221/jiiki.v8i01.324

Yonata, A., \& Pratama, A. S. P. (2016). Hipertensi sebagai Faktor Pencetus Terjadinya Stroke. Jurnal Majority, 5(3), 17-21.

http://juke.kedokteran.unila.ac.id/index.ph p/majority/article/view/1030 